\title{
Strategies for High-Performance Large-Area Perovskite Solar Cells toward Commercialization
}

\author{
Tianzhao Dai ${ }^{1,+}$, Qiaojun Cao ${ }^{1,+}$, Lifeng Yang ${ }^{1,2,3, *,+}$, Mahmoud H. Aldamasy ${ }^{4,5,{ }^{\dagger}}$, Meng Li ${ }^{5}\left(\mathbb{D}\right.$, Qifeng Liang ${ }^{1}$, \\ Hongliang $\mathrm{Lu}^{6, * \mathbb{C}}$, Yiming Dong ${ }^{1, *}$ and Yingguo Yang ${ }^{2,3, *}$
}

check for

updates

Citation: Dai, T.; Cao, Q.; Yang, L.; Aldamasy, M.H.; Li, M.; Liang, Q.; Lu, H.; Dong, Y.; Yang, Y. Strategies for High-Performance Large-Area Perovskite Solar Cells toward Commercialization. Crystals 2021, 11, 295. https://doi.org/10.3390/ cryst11030295

Academic Editor: $\mathrm{Gu} \mathrm{Xu}$

Received: 9 February 2021

Accepted: 25 February 2021

Published: 16 March 2021

Publisher's Note: MDPI stays neutral with regard to jurisdictional claims in published maps and institutional affiliations.

Copyright: (c) 2021 by the authors. Licensee MDPI, Basel, Switzerland. This article is an open access article distributed under the terms and conditions of the Creative Commons Attribution (CC BY) license (https:// creativecommons.org/licenses/by/ $4.0 /)$.
1 Department of Physics, Shaoxing University, Shaoxing 312000, China

2 Zhangijiang Lab, Shanghai Synchrotron Radiation Facility (SSRF), Shanghai Advanced Research Institute, Chinese Academy of Sciences, 239 Zhangheng Road, Shanghai 201204, China

3 Shanghai Institute of Applied Physics, Chinese Academy of Sciences, 2019 Jialuo Road, Shanghai 201800, China

4 Egyptian Petroleum Research Institute, Nasr, Cairo 11727, Egypt

5 Helmholtz-Zentrum Berlin für Materialien und Energie GmbH, Hahn-Meitner-Platz 1, Berlin 1410, Germany

6 Sch Microelect, State Key Lab ASIC \& Syst, Shanghai Inst Intelligent EI Elect \& Syst, Fudan University, Shanghai 200433, China

* Correspondence: yanglifeng@sinap.ac.cn (L.Y.); honglianglu@fudan.edu.cn (H.L.); yikouniao@usx.edu.cn (Y.D); yangyingguo@sinap.ac.cn (Y.Y.)

+ These authors contribute equally to this paper.

\begin{abstract}
Perovskite solar cells (PSCs) have received a great deal of attention in the science and technology field due to their outstanding power conversion efficiency (PCE), which increased rapidly from $3.9 \%$ to $25.5 \%$ in less than a decade, comparable to single crystal silicon solar cells. In the past ten years, much progress has been made, e.g. impressive ideas and advanced technologies have been proposed to enlarge PSC efficiency and stability. However, this outstanding progress has always been referred to as small-area $\left(<0.1 \mathrm{~cm}^{2}\right)$ PSCs. Little attention has been paid to the preparation processes and their micro-mechanisms for large-area $\left(>1 \mathrm{~cm}^{2}\right)$ PSCs. Meanwhile, scaling up is an inevitable way for large-scale application of PSCs. Therefore, we firstly summarize the current achievements for high efficiency and stability large-area perovskite solar cells, including precursor composition, deposition, growth control, interface engineering, packaging technology, etc. Then we include a brief discussion and outlook for the future development of large-area PSCs in commercialization.
\end{abstract}

Keywords: large-area Perovskite photovoltaic; efficiency; stability; commercialization

\section{Introduction}

Since the industrial age, the energy used by people has generally been fossil energy. The energy used by people earlier was mainly wood, in the 19th century, coal began to be used on a large scale, and oil and natural gas were used in the 20th century. The use of these fossil energy sources will inevitably cause environmental pollution and seriously affect people's health. For example, in the 19th century, London turned into a smog city, and China's smog, in previous years produced huge amounts of greenhouse gases (such as $\mathrm{CO}_{2}, \mathrm{CH}_{4}$ ), causing global warming and climate deterioration. Fossil energy is a nonrenewable energy source. Therefore, people have begun turning their attention toward renewable energy, among which, solar energy is undoubtedly the best, and use of solar cells is currently the most crucial way to make use of solar energy, by converting it into electric currents that could be utilized.

In recent years, perovskite solar cells (PSCs) have attracted worldwide attention due to their unique advantages. In just ten years, the PCE of PSCs has jumped from 3.8\% [1] to $25.5 \%$ [2] presently; it can be seen that it has great development potential and application prospects. However, most of the current PSCs are organometallic halide PSCs, which are easily affected by temperature and humidity, resulting in poor stability, and many of them 
are small-area PSCs, so they are not successfully embarked on the road of commercial production. Recently, Seo et al. in South Korea have developed a PSC with an area of $100 \mathrm{~cm}^{2}$ and a PCE of $18.8 \%$ [3]; and Groen et al. in the Netherlands have developed PSCs with an area of 144 and $160 \mathrm{~cm}^{2}$ with a PCE of $14.5 \%$ and $11 \%$ [4]. Meanwhile, Boyd et al. explained the degradation mechanism of perovskite-type optoelectronic materials and greatly improved their stability [5]. Miyasaka et al. provided in detail, the background, current situation, and prospects of halide perovskite photoelectric materials [6]. In this review, show the possibilities of PSC commercialization.

\section{Crystal Structure of Perovskite Materials}

The word perovskite was given to commemorate the discovery of $\mathrm{CaTO}_{3}$ by Russian mineralogist Lev Provski's team in 1983 [7]. Now, the perovskite in PSCs refer to metal halide perovskite; its general chemical formula is $\mathrm{ABX}_{3}$. A position is usually a monovalent metal cation, such as $\mathrm{Cs}^{+}$or $\mathrm{Rb}^{+}$, and it can also be an organic cation, such as methylamine and formamidine, etc. TheB position could be divalent metal cations $\mathrm{Pb}^{2+}, \mathrm{Sn}^{2+}, \mathrm{Bi}^{2+}$, etc.; $\mathrm{X}$ position is usually $\mathrm{I}^{-}, \mathrm{Br}^{-}, \mathrm{Cl}^{-}$and other halogen anions [8]. The stability of the crystal structure is usually determined by the tolerance factor $t$, which is expressed as:

$$
t=\frac{R_{A}+R_{B}}{\sqrt{2}\left(R_{A}+R_{X}\right)}
$$

$R_{A}, R_{B}, R_{X}$ represent the ionic radius of the corresponding ions. When $t$ lies in the range $0.8-1.0$, the cubic structure of Figure 1 is likely to occur. When $t$ is very small, the form of perovskite crystal will become a tetragonal or orthorhombic structure it will also become a cubic structure when it is subjected to a high temperature treatment. [9] In addition to $t$, there is another critical parameter that will affect the stability of the crystal, which is the octahedral factor $\mu$, expressed as [10,11]:

$$
\mu=\frac{R_{B}}{R_{X}}
$$

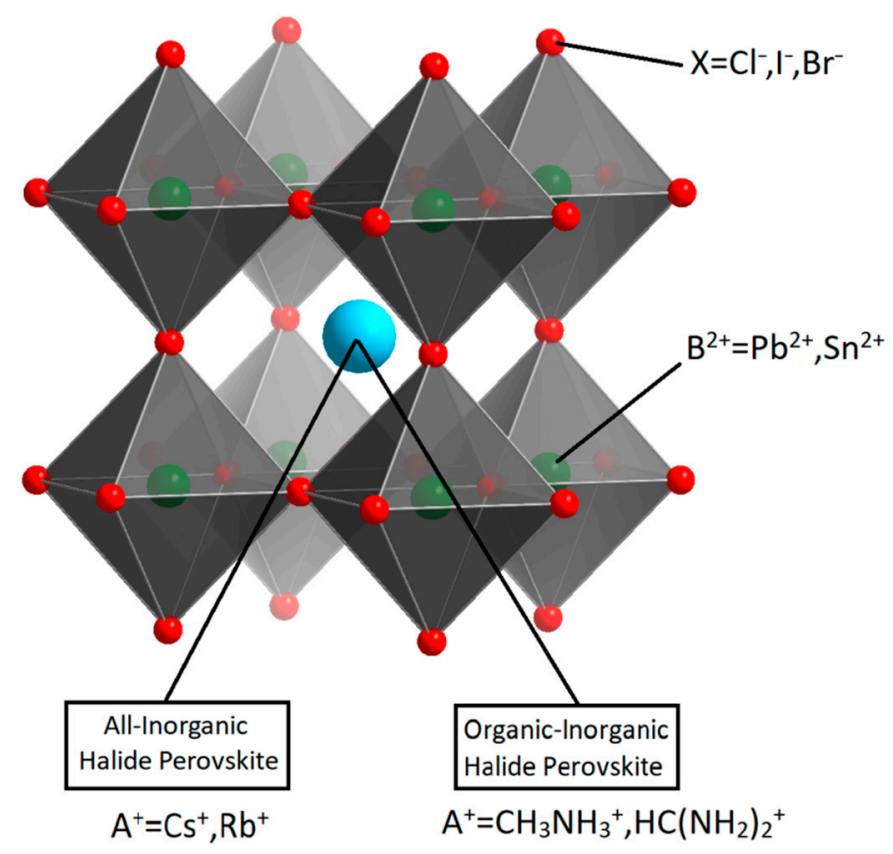

Figure 1. Schematic diagram of $\mathrm{ABX}_{3}$ lead halide perovskite crystal structure.

$R_{B}, R_{X}$ represents the ion radius of the corresponding ion. When $\mu$ is between 0.4 and 0.9 , it helps to form a stable $\mathrm{BX}_{6}$ octahedron. The $\mathrm{BX}_{6}$ octahedron also undergoes lattice 
distortion with changes in temperature, pressure, and stoichiometric ratio, leading to a series of phase transition processes [12].

\section{Research Progress of PSCs}

Figure 2 shows the efficiency transition of PSCs from 2009 to 2020. In 2009, Miyasaka et al. designed the first $\mathrm{PSC}$, which used $\mathrm{CH}_{3} \mathrm{NH}_{3} \mathrm{PbI}_{3}$ deposited $\mathrm{TiO}_{2}$ electrode as the photoelectrode (anode) and platinum-coated F-doped $\mathrm{SnO}_{2}$ glass as the counter electrode (cathode). The cathode and anode were inserted into a $50 \mu \mathrm{m}$ thick separation membrane, and the middle was filled with an organic electrolyte solution containing lithium halide and halogen. The effective light exposure area was $0.238 \mathrm{~cm}^{2}$, and the highest PCE achieved was $3.8 \%$ [1].

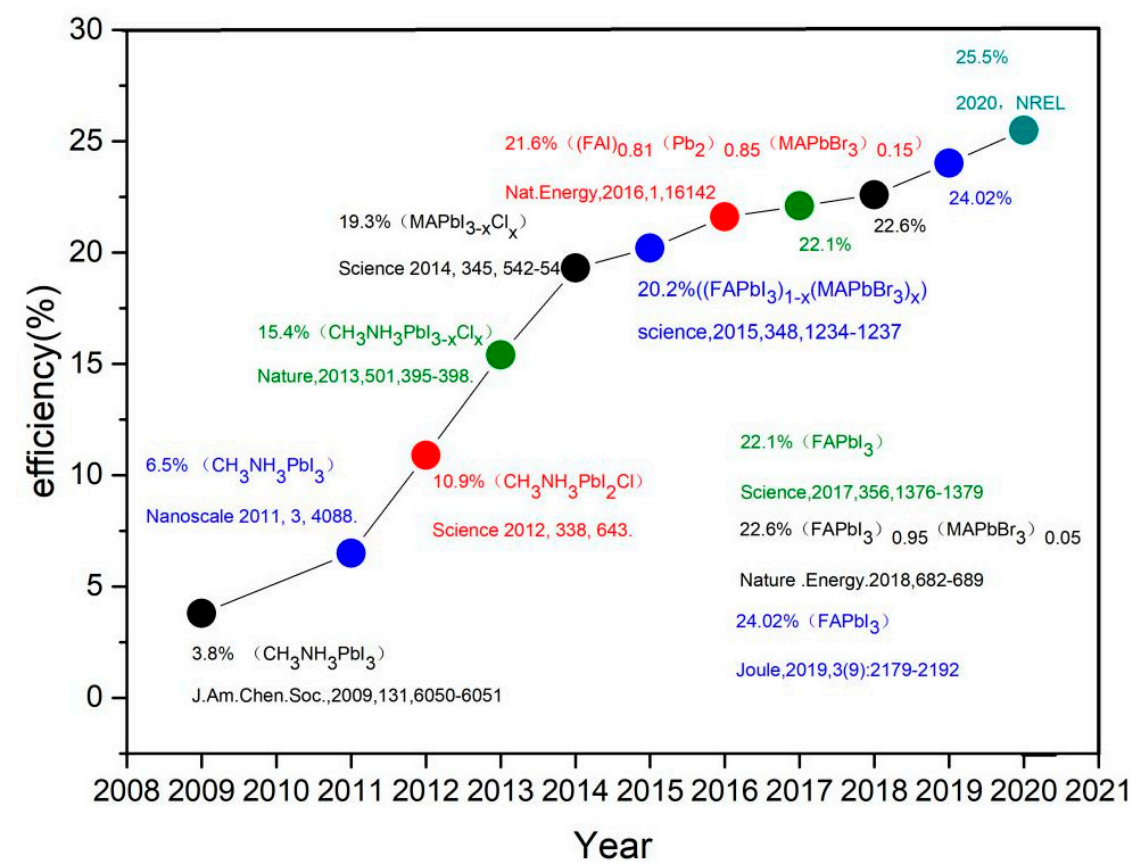

Figure 2. The evolution of the efficiency of perovskite solar cells (PSCs) from 2008 to 2020.

In 2011, Park et al. deposited a layer of $3.6 \mathrm{~mm}$ perovskite quantum dots on $\mathrm{TiO}_{2}$ and prepared a quantum dot-sensitized solar cell based on perovskite $\mathrm{CH}_{3} \mathrm{NH}_{3} \mathrm{PbI}_{3}$ as a sensitizer. The conversion efficiency reached $6.8 \%$, but it was degraded to $80 \%$ within $10 \mathrm{~min}$. The stability was very poor, and continuous research was needed to improve it [13].

In 2012, Snaith et al. reported a mixed-halide form $\left(\mathrm{CH}_{3} \mathrm{NH}_{3} \mathrm{PbI}_{2} \mathrm{Cl}\right)$ perovskite that exhibitedpower conversion efficiency near $11 \%$ [12]. They used the solid hole transport layer spiroOMeTAD $(2,2(7,7$ (-tetrakis-(N,N-di-pmethoxyphenylamine)9,9(-spirobifluorene)) as the transparent $\mathrm{P}$-type hole conductor, and replaced mesoporous $\mathrm{TiO}_{2}$ with $\mathrm{Al}_{2} \mathrm{O}_{3}$ as the transparent $\mathrm{N}$-type component. The $\mathrm{Al}_{2} \mathrm{O}_{3}$ has a wide band gap (7-9 eV), allowing $\mathrm{Al}_{2} \mathrm{O}_{3}$ to act as perovskite "scaffold" with mineral coating. This is conducive to the improvement of the electron transmission speed and open circuit voltage. Ultimately, the PCE of PSCs increased to $10.8 \%$ [14]. In 2013, Snaith et al. prepared a mixed halide perovskite $\mathrm{CH}_{3} \mathrm{NH}_{3} \mathrm{PbI}_{3-\mathrm{x}} \mathrm{Cl}_{\mathrm{x}}$ film using a vapor deposition method with dual sources. The PCE of PSCs reached $15.4 \%$ [15]. Later, people began to design new mixed -halide perovskite films to improve the PCE.

In 2014, Zhou et al. increased the PCE to $19.6 \%$ by suppressing the recombination of carriers [16]. In 2015, Yang et al. used the formamide lead iodide $\left(\mathrm{FAPbI}_{3}\right)$ perovskite, which had a bandgap that could absorb the solar spectrum more widely. It was prepared by an intramolecular exchange between dimethyl sulfoxide (DMSO) and methylammonium iodide. Then, its PCE reached 20.2\% [17]. This PCE is basically consistent with the PCE of silicon-based solar cells, so more people have begun to focus on preparing PSCs with 
a larger area and better stability. In the same year, Hen et al. designed large-area PSCs with an area of $1.017 \mathrm{~cm}^{2}$ and a PCE of $15 \%$. This PCE has passed the certification of an independent certification body. The manufacturing method of the large-area PSCs is based on using a heavily doped inorganic charge extraction layer in the planar PSCs. Even if the extraction layer is $10-20 \mathrm{~nm}$, the carrier can be extracted very quickly, which can avoid pinholes and eliminate local structural defects caused by large areas. Another stability milestone was achieved. Under $1000 \mathrm{~h}$ of light irradiation, the PCE can still be greater than the initial 90\% [18]. In 2019, his team produced soft PSCs with an aperture area of $1.02 \mathrm{~cm}^{2}$ and a PCE of $22.1 \%$. The method is to use a solution treatment strategy, utilizing a diluted $\mathrm{Pb}(\mathrm{SCN})_{2}$ solution as a $\mathrm{Pb}$ source, spin coating on the surface of the perovskite film, and then removing FASCN (methylamine thiocyanate) or MASCN (methyl thiocyanate) and other volatile organic components, forming a Pb-rich perovskite film on the surface, which will form strong chemical bonds on the surface of the soft perovskite film to stabilize the heterostructure of the perovskite, which will largely reduce the loss of the perovskite film, so that it can maintain $90 \%$ of its initial PCE after $1000 \mathrm{~h}$ of operation under the sunlight of $60{ }^{\circ} \mathrm{C}$ and AM1.5 [19].

In 2016, Grätzel et al. used polymethyl methacrylate (PMMA) as a template to prepare a high-quality perovskite film, which can effectively control nucleation and crystal growth, and due to the reduction of the nucleation free energy, heterogeneous nucleation speed is several orders of magnitude faster than uniform nucleation. Finally, a PSC with a PCE of $21.6 \%$ was achieved, and the certification PCE reached 21.02\% [20].

In 2017, Yang et al. introduced additional iodide ions into the organic cation solution to form a perovskite layer through an intramolecular exchange process, reducing the concentration of defects in the deep energy level, making the PCE of the small-area PSCs prepared to reach $22.1 \%$, and the PCE of the large-area PSCs with an area of 1 square centimeter was $19.7 \%$ [21].

In 2018, Lee et al. synthesized a terminal fluorene hole transport material with finetuned energy level and high glass transition temperature to ensure the high efficiency and stability of PSCs. The certified PCE of the small-area $\left(0.098 \mathrm{~cm}^{2}\right)$ PSCs reached $22.6 \%$, and the certification PCE of the large-area $\left(1 \mathrm{~cm}^{2}\right)$ PSCs reached $20.9 \%$, and it can work for more than $500 \mathrm{~h}$ in an environment of $60^{\circ} \mathrm{C}$ and still maintain $95 \%$ of the initial PCE [22].

In 2019, Kim et al. systematically studied the effect of methylammonium chloride $(\mathrm{MACl})$ additives in $\mathrm{FAPbI}_{3}$-based perovskites. Using the density functional theory, it could be concluded that the incorporation of $\mathrm{MACl}$ will affect the formation of the perovskite structure. When $40 \mathrm{~mol} \% \mathrm{MACl}$ is added, the best PSC can be manufactured, the grain size increased by six times, the phase crystallinity increased by three times, and the photoluminescence lifetime increased by 4.3 times. The highest PCE reached $24.02 \%$, and the certification PCE reached $23.48 \%$ [23].

\section{Challenges and Solutions for Manufacturing Large-Area PSCs}

Before 2015, most studies focused on the properties and stability of PSCs, the area of PSCs, is generally less than $0.1 \mathrm{~cm}^{2}$. Many studies were pursuing high PCE to prove that PSCs were not weaker than other solar cells. In 2015, the PCE of PSCs broke through $20 \%$, which is at the same level as the PCE of silicon-based solar cells. After that, scientists began to focus on designing large-area PSCs with bigger size and greater stability, and, finally, can be commercialized. This year, Han et al. published their work in Science [18], in which the concept of large-area PSCs was proposed. In this work, they designed PSCs with an area larger than $1 \mathrm{~cm}^{2}$, and the PCE reached $15 \%$. Moreover, its stability had also been greatly improved; after $1000 \mathrm{~h}$ of work under light irradiation, it retains more than $90 \%$ of the initial PCE. Subsequently, more people began to prepare large-area perovskite films. The area of PSCs is mainly about $1 \mathrm{~cm}^{2}$ because as the area increases, the stability and PCE of the PSCs will decline rapidly. It is challenging to have the best of both worlds.

After 2015, more people began to manufacture large-area perovskite films, but there was always a significant gap in PCE between large-area and small-area PSCs. As the area 
of PSCs increases, the stability and PCE of PSCs will decline rapidly, as shown in Figure 3. There are three main reasons for these behaviors. Firstly, when the device active area becomes larger, the crystal uniformity in perovskite film will inevitably decrease, and cells in series will lead to an increase in resistance. Secondly, the repeatability of large-area PSCs is poor. When manufacturing small-area PSCs in a laboratory, it is generally under a strict environment (control of humidity and temperature). In order to achieve excellent PCE, the cost is not considered. However, there are no such conditions for large-area PSCs, we have to manufacture PSCs that can be used generally in reality, and tolerant to the environment. Thirdly, people have just transitioned from small-area to large-area PSCs; the method of manufacturing small-area PSCs is not suitable for manufacturing large-area PSCs. For example, a spin-coating process is generally used to manufacture small-area PSCs instead of blade coating or slot-die coating. However, to manufacture large-area PSCs, blade coating and slot-die coating are needed.

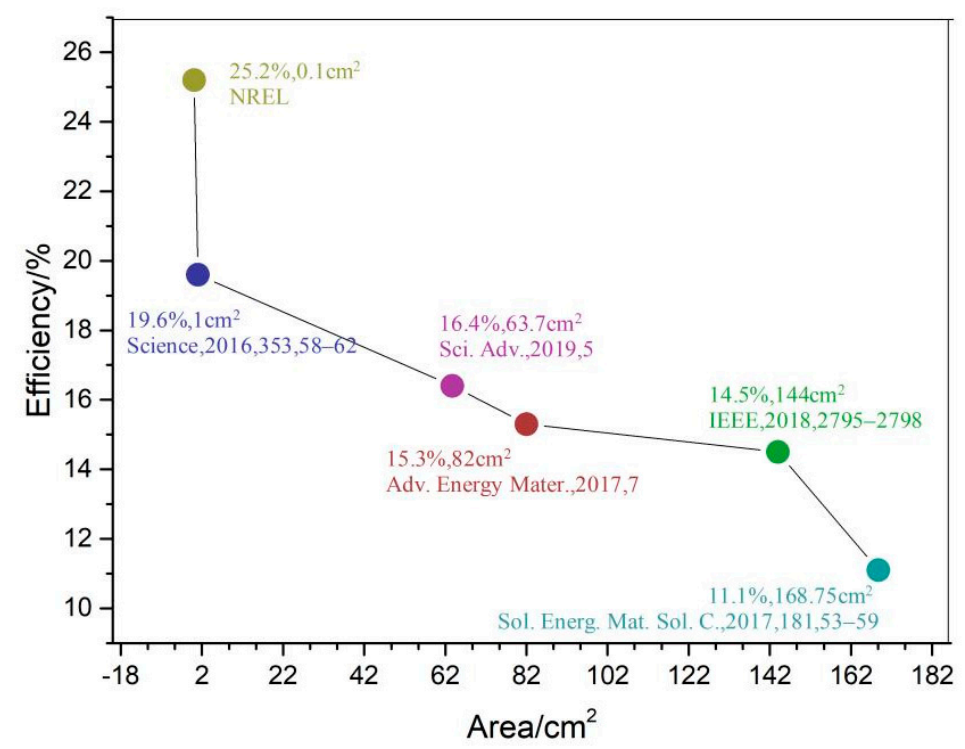

Figure 3. Relationship between power conversion efficiency (PCE) and device active area.

Currently, there are mainly six ways to increase the efficiency and stability of largearea PSCs.

(1) Find a suitable process for manufacturing large-area PSCs and improve this process. In the past, the spin-coating process was generally used to manufacture small-area PSCs, but this is not suitable for large-area PSCs. Currently. more processes that could be used to manufacture large-area PSCs. For example, blade coating [24,25], slot-die coating [26-28], inkjet printing [29-31], screen printing [32,33], spray coating [34,35], vapor phase deposition [35-37] and electrodeposition [38,39]. These processes can more effectively manufacture large-area solar cells.

(2) The efficiency and stability of the PSCs can be improved by improving the precursor solution or finding materials with better performance (including longer carrier diffusion length, higher absorption coefficient, etc.). These factors will effectively help us make PSCs with better efficiency and larger areas.

(3) Add better additives to the precursor solution. Adding different additives will have different effects. For example, adding thiourea or thiosemicarbazide to $\mathrm{MAPbI}_{3}$ precursor can increase the grain size of perovskite film and improve device performance [40,41]. Adding cadmium (Cd) and aluminum ( $\mathrm{Al}$ ) ions can increase photoluminescence and reduce electron defect density $[42,43]$. Adding lead thiocyanate $\left(\mathrm{Pb}(\mathrm{SCN})_{2}\right)$ and $\mathrm{PCBM}([6,6]-$ phenyl-C61-butyric acid methyl ester) can improve the fill factor of device performance [44,45]. 
(4) Interface engineering. Good interface matching can reduce or even eliminate the $\mathrm{J}-\mathrm{V}$ (current-voltage) hysteresis of PSCs, thereby reducing the interface recombination and improving PSC stability and PCE.

(5) Packaging technology, encapsulation of PSCs is essential, which can help PSCs avoid interference from the external environment, limit the exposure of oxygen and moisture, and greatly improve PSC stability.

(6) Growth control. By artificially controlling the growth of perovskite crystals, perovskite films with larger grains and better uniformity can be grown, improving the PCE and stability of PSCs.

The following is a specific introduction to the achievements of these six methods.

\subsection{Processes Improvement}

In 2016, Grätzel et al. used the most advanced perovskite $\mathrm{FA}_{0.81} \mathrm{MA}_{0.15} \mathrm{PbI}_{2.51} \mathrm{Br}_{0.45}$ and a simple way to design large-area perovskite films. The method was a vacuum flash solution treatment, which can quickly control solvent' removal and promote fiber material rapid crystallization. After thermal annealing, highly oriented perovskite crystal films with excellent electronic quality can be grown on various substrates, and the hysteresis in the current-voltage $(\mathrm{J}-\mathrm{V})$ curve is eliminated. A large-area cell with an area of $1 \mathrm{~cm}^{2}$ was obtained. The maximum PCE was 20.5\%, and the certified PCE reached 19.6\% [46].

In 2018, Groen et al. considered that it was necessary to improve a process to deposit the constituent layers over large areas efficiently, so they optimized the application of the slot die coating process in sheet-to-sheet (S2S) and roll-to-roll (R2R) manufacturing. Moreover, the uniformity of perovskite crystallization is controlled by adjusting the ink formulation and drying process. This technique helps large-area perovskite film without excessive loss even after an increase of thee orders of magnitude (from $0.09 \mathrm{~cm}^{2}$ to $144 \mathrm{~cm}^{2}$ ). Finally, a large-area PSC of $144 \mathrm{~cm}^{2}$ was manufactured (Figure 4), with a stable PCE of $13.8 \%$ and an active-area PCE of $14.5 \%$ [ 4$]$.

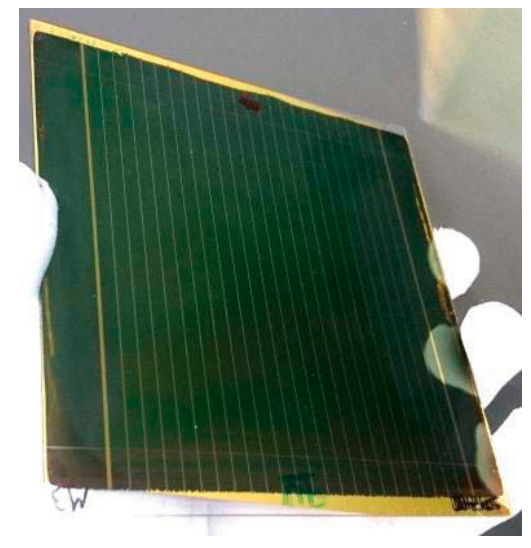

Figure 4. Picture of a $144 \mathrm{~cm}^{2} \mathrm{~S} 2 \mathrm{~S}$ perovskite module. Copyright Reproduced with permission from Reference [4].

In the same year, Seo et al. proposed a fast and simple two-step method to design high-quality perovskite films, namely mediator extraction treatment (MET) [3]. Compared with other methods for fabricating perovskite films, this method can significantly improve the preparation of large-area PSCs. The two most representative methods are solvent engineering and two-step sequential deposition. The crystal growth process of solvent engineering usually only takes a few seconds, and the repeatability is poor, especially for large-area perovskite films; The two-step sequential deposition is a more controllable and reliable method that can fabricate large-area perovskite films with high uniformity. However, it takes at least one hour when the $\mathrm{PbI}_{2}$ layer is completely transformed into perovskite, which is too long. MET can significantly reduce the time of this step. They first deposited $\mathrm{PbI}_{2}$-DMSO film, then DMSO mediators were extracted efficiently and rapidly 
by optimizing casting solvent and anti-solvent. Afterward, the $\mathrm{PbI}_{2}$ film can form a porous morphology with relatively random crystal orientation within a few seconds, helping $\mathrm{PbI}_{2}$ to be wholly and quickly converted into perovskite. In this way, a $100 \mathrm{~cm}^{2} \mathrm{PSC}$ was fabricated (Figure 5). The maximum PCE of PSCs fabricated using spin coating is 18.8\%, and the maximum PCE of PSCs fabricated using slot-die coating is $18.3 \%$.

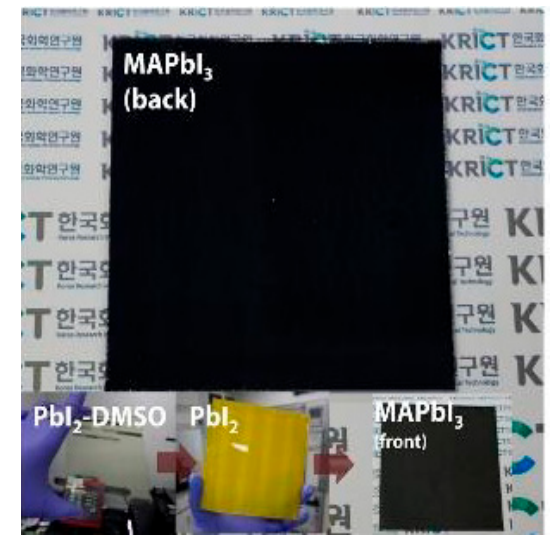

Figure 5. Picture of $100 \mathrm{~cm}^{2}$ perovskite thin film produced by slot-die coating. Copyright Reproduced with permission from Reference [3].

In 2020, Mai et al. used the self-assembly one-step printing process to manufacture $2 \mathrm{D} / 3 \mathrm{D}$ heterostructure $\mathrm{MAPbI}_{3}$ for the first time. Unlike the previous two-step deposition to prepare $2 \mathrm{D} / 3 \mathrm{D}$ heterostructures, they grew a thin layer of two-dimensional perovskite in situ on top of the 3D-MAPbI3 perovskite body. Because of the amine $\left(-\mathrm{NH}_{2}\right)$ and carboxyl $(-\mathrm{COOH})$ functional groups in the macromolecular SBLC, it can repair the charged defects of the perovskite and reduce non-radiative recombination [47-49]. Secondly, better 2D/3D interfaces can be obtained through the interaction of the hydrogen-halogen bonding and the 3D Perovskite, thereby reducing the 2D/3D interface recombination. Thirdly, due to unpaired electrons in the sulfur atom, SBLC can act as a Lewis base and cooperate with $\mathrm{PbI}_{2}$ to increase crystal size by slowing down crystal growth [50]. Through one-step scraping and vacuum quenching crystallization, a thin layer of 2D perovskite can be perfectly selfassembled to cover the surface of 3D Pperovskite. The 2D layer of Perovskite on the surface can effectively passivate the surface defects of the 3D Perovskite, inhibit non-radiative recombination, and greatly increase the open circuit voltage. Finally, large-area PSCs with an active area of $10.08 \mathrm{~cm}^{2}$ was manufactured, and its PCE was as high as $15.38 \%$. It also has good thermal stability and light stability and can retain $80.9 \%$ of the original PCE after 30 days of storage in ambient air [51].

\subsection{Improvement of the Precursor Solution and Better Materials Utilization}

In 2017, Marks et al. used a one-step hot-casting perovskite system, which is different from the original use of $\mathrm{PbI}_{2}$ and $\mathrm{MACl}$ to make $\mathrm{MAPbI}_{3}$. They used $\mathrm{PbI}_{2}$ and MAI salts (1:1 molar ratio) to hot-cast $\mathrm{MAPbI}_{3}$. This method can control the incorporation of $\mathrm{Cl}^{-}$to reduce recombination, increase the carrier diffusion length, and improve the perovskite film's morphology and the halide concentration gradient in the entire perovskite film. In addition, $\mathrm{Cl}^{-}$can also enhance the stability of the device by passivating the reaction between $\mathrm{I}^{-}$and the silver electrode. Using this method, a $25 \mathrm{~cm}^{2}$ perovskite film was fabricated by the dip-coating process, and the active-area PCE is 12\% [52].

In the same year, Huang et al. created a new type of quadruple-cation perovskite absorber $\mathrm{KxCs}_{0.05}\left(\mathrm{FA}_{0.85} \mathrm{MA}_{0.15}\right)_{0.95} \mathrm{~Pb}\left(\mathrm{I}_{0.85} \mathrm{Br}_{0.15}\right)_{3}$ (denoted as KCsFAMA) by adding potassium ions. Its most outstanding feature is that it can eliminate the hysteresis in PSCs. It also has good stability and can keep the efficiency unchanged even after $1000 \mathrm{~h}$ of storage in the ambient air. The addition of potassium can also help the perovskite film crystallize quickly, and the resulting grain size is as high as $1 \mu \mathrm{m}$, which is twice the size of the control film 
without potassium. With KCsFAMA, perovskite films with lower interface defect density, longer carrier lifetime, and faster charge transfer speed can be produced. In this work, $6 \times 6 \mathrm{~cm}^{2}$ PSCs were fabricated with an active area of $20 \mathrm{~cm}^{2}$ and a PCE of $15.76 \%$ [53].

In 2019, Bonaccorso et al. pioneered the use of 2D graphene and functionalized $\mathrm{MoS}_{2}$ in PSCs. The use of 2D materials effectively improved the stability and overall PCE of the PSCs and successfully fabricated a large-area PSC of $108 \mathrm{~cm}^{2}$. The PCE of the active area reached $13.4 \%$, and it can work at $65{ }^{\circ} \mathrm{C}$ for $1000 \mathrm{~h}$; its PCE can retain $75 \%$ of the initial value [54].

In 2020, Jeong et al. wanted to optimize the organic hole transport materials (HTM). However the latest HTM, including cesium cation [55,56], carbon electrode [57-59], and dopant free-based PSCs $[60,61]$, has lower PCE than Spiro-OMeTAD-based PSCs. They decided to optimize Spiro-OMeTA by taking into account multiple possible aspects of the fluorination of conjugated materials (for example, dipoles induced by C-F bonds reduce energy levels and enhance molecular packing and hydrophobicity), two fluorinated isomeric analogs (Spiro-mF and Spiro-oF) were developed as HTMS for PSC preparation (Figure 6 shows Chemical structures of Spiro-OMeTAD and its fluorinated analogs Spiro$\mathrm{mF}$ and Spiro-oF). Compared to the optimized Spiro-OMeTAD-based PSC, it is found that the performance of the PSC made with Spiro-mF is superior. Its PCE is $24.82 \%$ (certified PCE is $24.64 \%$, the loss is $0.3 \mathrm{~V}$ ), and it can still maintain $87 \%$ of the original PCE after $500 \mathrm{~h}$ under high relative humidity and no packaging. Besides, the fabricated $1 \mathrm{~cm}^{2}$ large-area PSC has a PCE of $22.31 \%$ [62].

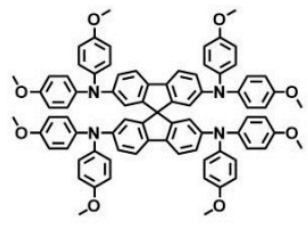

Spiro-OMeTAD

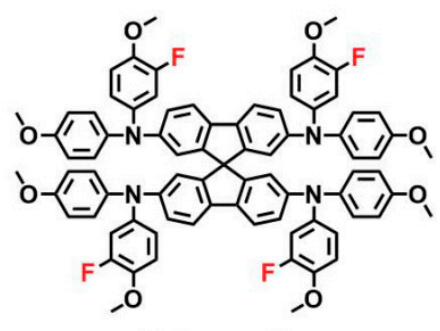

Spiro- $m \mathbf{F}$

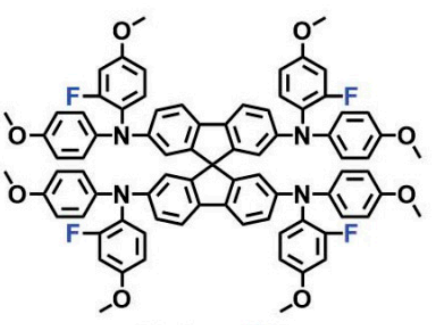

Spiro-oF

Figure 6. Chemical structures of Spiro-OMeTAD and its fluorinated analogs Spiro-mF and Spiro-oF. Copyright Reproduced with permission from Reference [62].

\subsection{Additives Addition to the Precursor Solution}

In 2019, by improving the additives added to the precursor solution, Deng et al. created an unprecedented method that can quickly coat a large area of perovskite film at a speed of $99 \mathrm{~mm} / \mathrm{s}$ at room temperature. In order to have this speed, they studied dimethyl sulfoxide (DMSO), dimethylformamide (DMF), gamma-butyrolactone (GBL), 2-methoxy ethanol (2-ME), and acetonitrile (ACN) coordination ability with MAPbI3 [63,64]. They found that common solvents (such as DMSO and DMF) are not conducive to the rapid deposition of dense and smooth perovskite films at room temperature. The high volatility of 2-ME and ACN will result in low crystallinity of perovskite films and poor contact to the substrate. However, when the two solvents are combined in a particular ratio, it is surprisingly found that this new additive not only has the advantages of both but also avoids their disadvantages. In addition, new additives were slowly released from the coated solid film, thereby providing enough time for the perovskite grains to grow into a large-size perovskite film with high crystallinity and good contact with the substrate. Finally, a PSC with excellent resistance to temperature and shading was manufactured, with an aperture area of $63.7 \mathrm{~cm}^{2}$ and a certification PCE of $16.4 \%$ [65].

In 2019, Huang et al. discovered a new class of additives; that is, surfactants (for example, $\mathrm{L}-\alpha$-phosphatidylcholine). As long as a very small amount of surfactant is added, the solution flow dynamics in the dry ink layer can be significantly inhibited, and the adhesion of the perovskite ink to the underlying non-wetting charge transport layer can 
be increased. This facilitates the solution deposition of large-area pinhole-free organicinorganic perovskite films. Some surfactants also have a passivation effect, which can further improve device performance. In their research, they added $20 \mathrm{ppm}$ of surfactant to the perovskite ink, which helped them to obtain high-quality perovskite films at a highspeed coating of $180 \mathrm{~mm} / \mathrm{h}$. The PCE of the small-area PSCs obtained by this method is more than $20 \%$. When the aperture area is $33.0 \mathrm{~cm}^{2}$ and $57.2 \mathrm{~cm}^{2}$, the PCE of $15.3 \%$ and $14.6 \%$ are obtained, respectively [66].

In 2020, Huang et al. used a slot-die coating process and then heated it with nearinfrared radiation. They then added a low boiling point and low surface tension n-butanol to the precursor solution to increase near-infrared energy absorption. Promote the evaporation and film formation of the solvent system and accelerate the crystallization of perovskite. Finally, four layers of $12 \times 12 \mathrm{~cm}^{2}$ uniform and high-quality perovskite film can be fabricated within $18 \mathrm{~s}$, and its PCE reached $10.96 \%$. (Figure 7 and Table 1) The fabricated single-layer $12 \times 12 \mathrm{~cm}^{2}$ large-area PSC with a PCE of $14.3 \%$ [67].

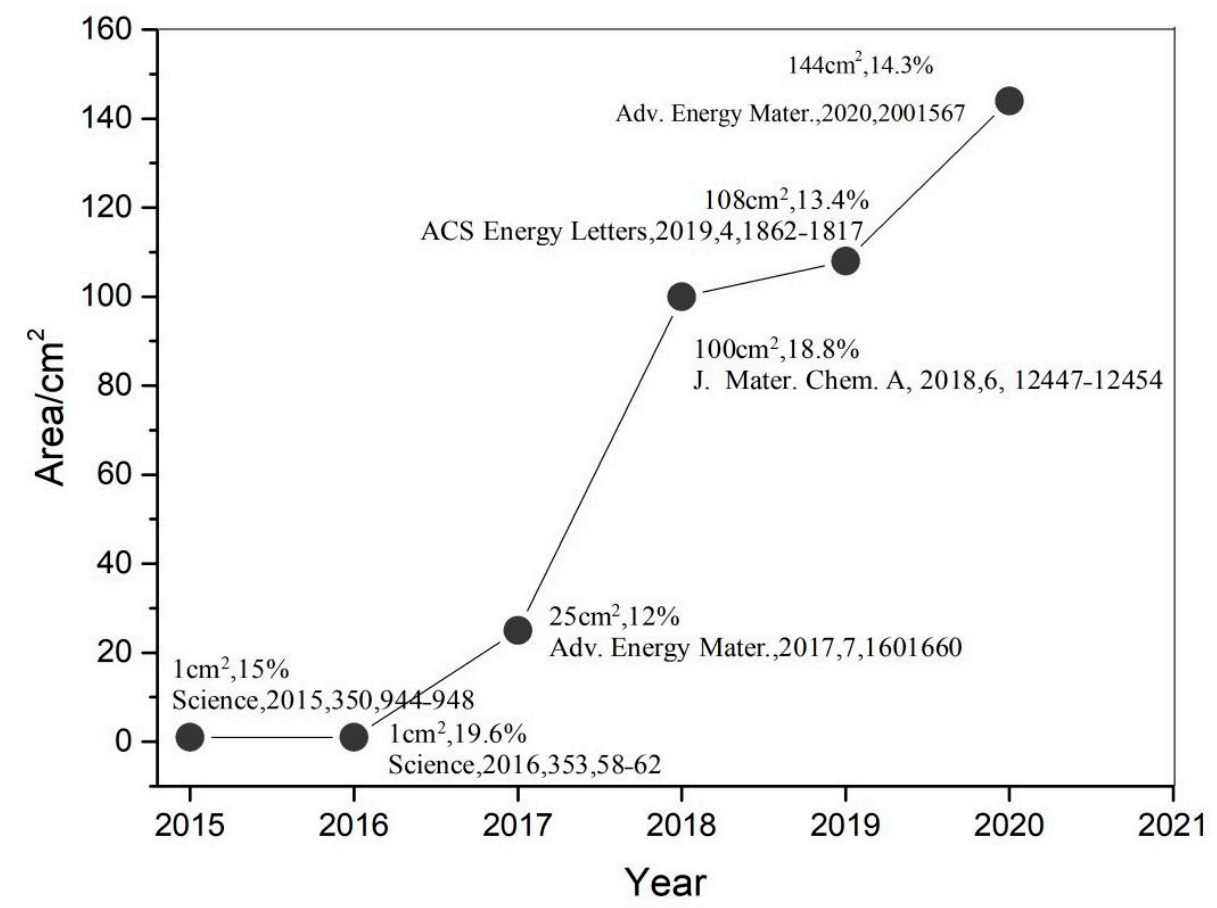

Figure 7. The changing trend of PCE and area of large-area PSCs from 2015 to 2020.

Table 1. A list of some excellent works on large-area PSCs.

\begin{tabular}{cccccc}
\hline Area/cm & Efficiency/\% & Country & Institution/Unit & Corresponding Author \\
\hline 2 & 15.1 & Singapore & NTU & Leong, W. L [68] \\
\hline 24.97 & 16 & South Korea & Korea Research Institute of Chemical Technology & Noh, J. H [69] \\
\hline 36 & 15 & China & Shanghai Jiao Tong University & Yang, X. D [70] \\
\hline 52 & 10.2 & China & Peking University & Zheng, S. Z [71] \\
\hline 64 & 12.24 & China & WuHan University & Peng, Y [72] \\
\hline 80 & 17.28 & South Korea & Yonsei University & Moon, J [73] \\
\hline 91.8 & 10.4 & Japan & Okinawa Institute of Science and Technology & Qi, Y. B [74] \\
\hline 168.75 & 11.1 & Italy & University of Rome Tor Vergata & Galagan, Y [75] \\
\hline
\end{tabular}




\subsection{Interface Engineering}

In 2016, Wang et al. realized that interface engineering and perovskite crystallization are the most critical factors for realizing high-performance planar heterojunction PSCs. Therefore they demonstrated a solution processing method to make thin perylene as the underlayer of PSCs. (Figure 8) Using branch-shaped perylene film as a seed-mediated underlayer can form perovskite crystals with a textured morphology, thereby significantly improving absorption through light scattering effects. Because the perylene has a deep highest occupied molecular orbital (HOMO) energy level, it also plays a vital role in poly $(3,4-$ ethylene dioxythiophene): poly(styrene sulfonate) (PEDOT:PSS), and $\mathrm{CH}_{3} \mathrm{NH}_{3} \mathrm{PbI}_{\mathrm{x}} \mathrm{Cl}_{3-\mathrm{x}}$ energy level tailoring. In addition, perylene and perovskite form a complete crystalline heterostructure, which helps to minimize defect and trap densities. Due to these advantages, the PCE of PEDOT:PSS based PSCs is increased from $12 \%$ to more than $17 \%$, which reduces the J-V hysteresis effect and improves the stability of the device. This technique provides a simple way to control the crystallization of perovskite and optimize the interface in the planar heterostructure PSC [76].

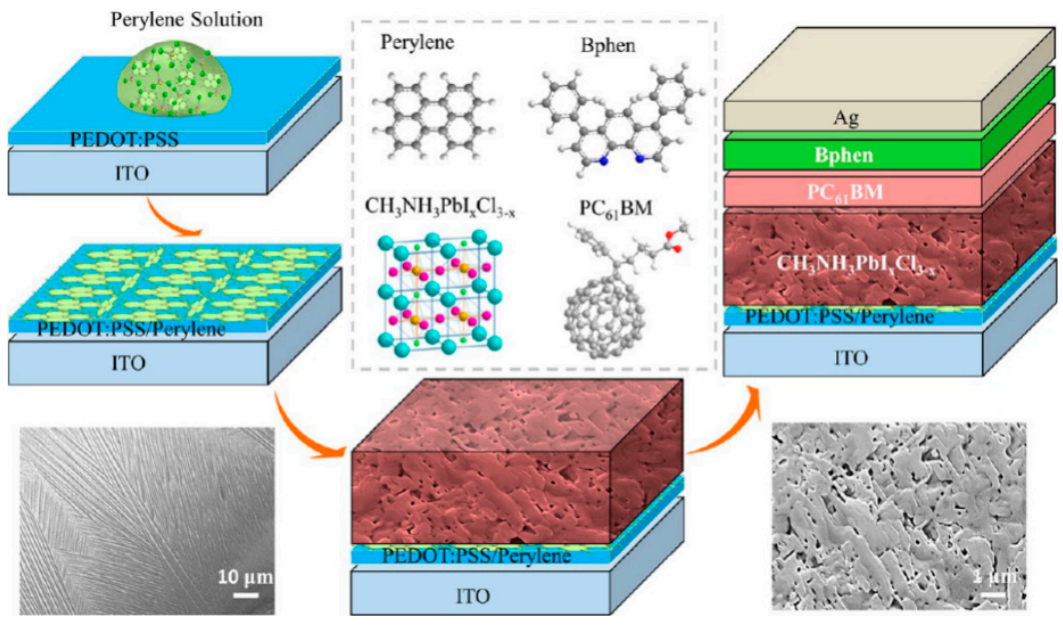

Figure 8. Chart flow of the device fabrication of a planar PSC and the molecule structures of the materials used in the device. Bottom left: SEM image of branch-shaped perylene films. Bottom right: SEM image of fabric $\mathrm{CH}_{3} \mathrm{NH}_{3} \mathrm{PbIxCl}_{3-\mathrm{x}}$ films deposited on the branch shaped perylene underlayer. Copyright Reproduced with permission from Ref. [76].

In 2017, Tan et al. believed that performance and stability losses of low-temperature planar PSCs may be caused by the imperfect interface and charge recombination between the selective contact on the illumination side and the perovskite film grown on top [77-79], because the perovskite active layer itself has good long-term light stability after adding formamidinium (FA), Cs and Br ions [18,47,56,80,81]. They believe that when the perovskite film has an excellent long photocarrier diffusion length, attention should be directed to the perfect interface [82-85]. Therefore, they used a modified $\mathrm{TiO}_{2}$ nanocrystalline film formed by doping $\mathrm{Cl}$ ions as an electron selective layer, which can reduce interfacial recombination and improve the interfacial bonding of low-temperature planar PSCs. After the produced solar cell is treated with a low-temperature solution, the final area is $1.1 \mathrm{~cm}^{2}$, and the PCE is as high as $20.1 \%$. Moreover, it also pronounced high stability, after $500 \mathrm{~h}$ of continuous operation at room temperature with the maximum power under one sun illumination, its performance remains $90 \%$ of the initial value (97\% after dark recovery) [86].

In 2019, Yang et al. wanted to develop a high-quality electron transport layer (ETL) with suitable energy levels and high electron mobility. However, the charge carrier transport efficiency is also very sensitive to the morphology of various interfaces in the PSCs; the interface morphology between ETL and perovskite must be controlled to promote carrier transport to obtain ideal device performance [87]. They used a new low-temperature processing $\mathrm{SnO}_{2}$ instead of $\mathrm{TiO}_{2}$, which has a more suitable energy level and higher elec- 
tron mobility $[88,89]$. However, the mobility of $\mathrm{SnO}_{2}$-ETL $\left(10^{-3} \mathrm{~cm}^{2} \mathrm{~V}^{-1} \mathrm{~s}^{-1}\right)$ is very low compared to $\mathrm{CH}_{3} \mathrm{NH}_{3} \mathrm{PbI}_{3}\left(0.5^{-30} \mathrm{~cm}^{2} \mathrm{~V}^{-1} \mathrm{~s}^{-1}\right)[90,91]$, this is not suitable as an ETL candidate. Therefore, they used red-carbon quantum dots (RCQs) rich in carboxylic acids and hydroxyl groups doped with low-temperature solution-treated $\mathrm{SnO}_{2}$ to produce effective composite ETL. This significantly increased its electron mobility from $9.32 \times 10^{-4}$ to $1.73 \times 10^{-2} \mathrm{~cm}^{2} \mathrm{~V}^{-1} \mathrm{~s}^{-1}$, which is about a 20 time increase (this is the highest electron mobility of $\mathrm{SnO}_{2}$ ) (Figure 9). After RCQs doping, the surface of $\mathrm{SnO}_{2}$ becomes more hydrophilic, which indicates that the Gibbs free energy on the surface is reduced, which is conducive to the non-uniform nucleation of perovskite and produces high-quality perovskite films [92]. The PCE of the new $\mathrm{SnO}_{2}$-ETL planar PSCs was increased from $19.15 \%$ to $22.77 \%$. Moreover, the long-term stability against humidity was enhanced. After $1000 \mathrm{~h}$ at $25^{\circ} \mathrm{C}$ and $40-60 \%$ humidity, it still maintains a PCE of $95 \%$ of the initial efficiency [93].

(a)

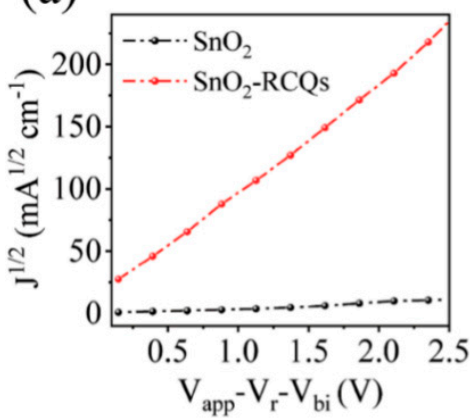

(c)

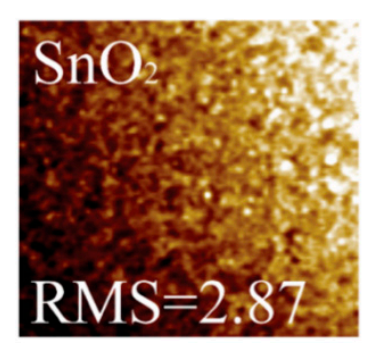

(b)

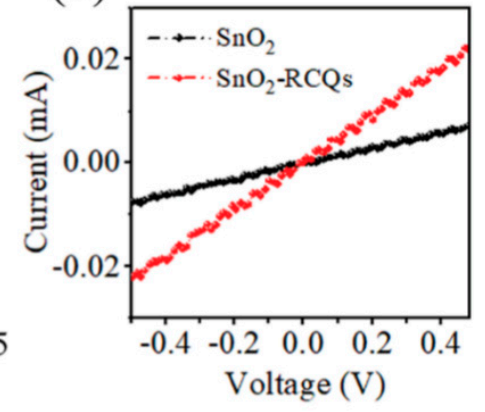

(d)

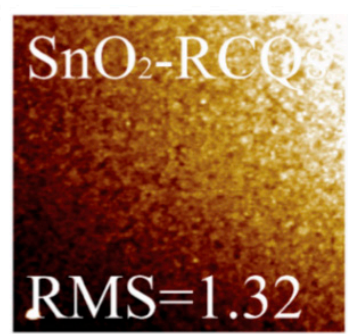

Figure 9. (a) J-V characteristics of the electron-only devices based on the $\mathrm{SnO}_{2}-\mathrm{RCQ}$ and $\mathrm{SnO}_{2}$ electron transport layers (ETLs), from which their electron mobility was calculated from the SCLC model. (b) Conduction properties of the $\mathrm{SnO}_{2}$ films with and without red-carbon quantum dots (RCQs). (c,d) AFM height images of the $\mathrm{SnO}_{2}$ and $\mathrm{SnO}_{2}$-RCQs films, respectively. Copyright Reproduced with permission from Ref. [92].

\subsection{Packaging Technologies}

In 2016, Bella et al. prospected to improve the stability and efficiency of PSCs through packaging technology. Some groups reported the hydrophobic polymer layers to limit atmospheric moisture [94,95], others used metal oxide (for example, chromium oxidechromium $\left.\left(\mathrm{Cr}_{2} \mathrm{O}_{3} / \mathrm{Cr}\right)\right)$ interlayers to protect organic components, protect metal contacts from the reaction of perovskite materials, and produce PSCs with all-solution-processed metal oxide charge transport layers [96-98]. These methods are only considering the damage of the air to the device. Bella et al. used a multifunctional photopolymer as an excellent solution to solve PSCs instability. Moreover, a luminescence downshifting (LDS) fluoropolymer layer is rapidly photogenerated on the front side of the device (i.e., the glass surface). The coating prevents the ultraviolet part of the incident solar spectrum from negatively interacting with the PSC stack by converting the ultraviolet part of the incident solar spectrum into visible light and increases the photocurrent by $6 \%$. Due to atmospheric humidity tolerance, a robust hydrophobic photopolymer is grown on the back contact side. This additional layer acts as an effective barrier to prevent water penetration in the solar cell stack. The PCE of the finally manufactured PSCs was 18.67\%. In the 180-day (4320 h) 
aging test, under different atmospheric conditions and various photochemical external stresses, the resulting device showed unparalleled stability. The same device was also exposed to a real outdoor environment for more than three months $(2160 \mathrm{~h})$, successfully demonstrating its excellent resistance to dust, soil, and heavy rain on the external glass surface. Finally, the low surface energy fluorinated LDS layer makes the front electrode easy to clean under actual outdoor conditions. In order to prove the water-resistance of the photopolymerized fluorinated coating, the PSC was put into a beaker filled with boiling water (95\%RH). One month later, the PSC had $96 \%$ of the initial PCE [99].

In 2017, Lee et al. expected to improve the stability of PSCs through customized thinfilm encapsulation (TFE) and then developed a new method to integrate TFE directly on the PSCs to improve the humidity resistance of the device. This method is an organic/inorganic multilayer TFE system, which is made by combining initiated chemical deposition (iCVD) and atomic layer deposition (ALD) processes [100-102]. A pair of $\mathrm{Al}_{2} \mathrm{O}_{3}$ inorganic layer and pV3D3 organic layer is called a dyad, which has excellent barrier properties. This is the first use of iCVD and ALD processes to apply multilayer TFE to PSCs packaging (Figure 10). In order to improve its long-term stability in a humid environment, the TFE structure and deposition conditions were optimized, and the purge time after water injection was adjusted to reduce the ALD process temperature to minimize equipment damage during the TFE deposition step. The first organic layer manufactured by iCVD serves as the main protective film for PSC. TFE was prepared at low temperature using $60{ }^{\circ} \mathrm{C}$-ALD and $40{ }^{\circ} \mathrm{C}$-iCVD processes to deposit $\mathrm{pV} 3 \mathrm{D} 3 / \mathrm{Al}_{2} \mathrm{O}_{3}$ multilayer films. Under the accelerated conditions of $38{ }^{\circ} \mathrm{C}$ and $90 \% \mathrm{RH}$, its water vapor transmission coefficient was $10^{-4} \mathrm{~g} \mathrm{~m}^{-2} \mathrm{~d}^{-1}$, showed excellent barrier properties. Moreover, the packaging process is significantly improving the stability without degrading the performance of the device. The PSCs can be exposed to $50{ }^{\circ} \mathrm{C}$ and $50 \%$ relative humidity for $300 \mathrm{~h}$, and its PCE still has $97 \%$ of the initial value [103].

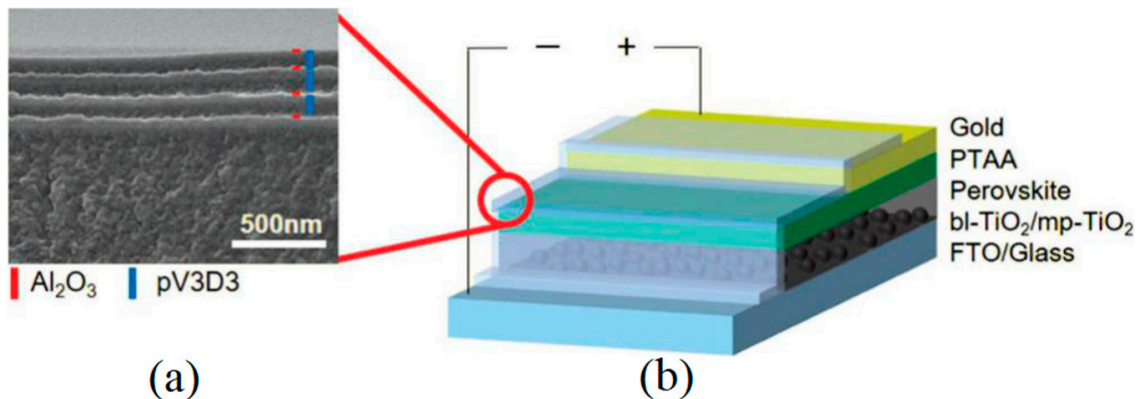

Figure 10. (a) The cross-sectional SEM image of the TFE, and (b) Schematic illustration of the encapsulated PSC. Copyright Reproduced with permission from Ref. [103].

In 2020, Emami et al. developed an advanced laser-assisted glass-frit encapsulation method to seal PSCs without hole transport material (HTM). They had already known that the performance loss of HTM-based PSCs is caused by the thermal instability of the HTM layer at $100{ }^{\circ} \mathrm{C}$, moreover, the glass-frit has excellent airtightness and stability compared with ordinary thermoplastics, and the laser beam can locally heat the sealant material to its melting point while keeping the device at a lower process temperature. Since the laserassisted sealing process temperature and dwell time will affect the performance of the PSCs device, they established a response surface method (RSM), model. The model included two-factor variables (sealing process temperature and heating dwell time) and three-factor responses (sealing quality, sealing reproducibility, and the effect of the sealing process on the performance of PSCs device) to minimize the above effects. They finally produced PSCs that can pass 70 thermal cycles $\left(-40{ }^{\circ} \mathrm{C}\right.$ to $\left.85^{\circ} \mathrm{C}\right)$ and $50 \mathrm{~h}$ of damp heat $\left(85^{\circ} \mathrm{C}\right.$, $85 \% \mathrm{RH}$ ) test according to the IEC 61646 standard. This is the first report of the packaging method that can pass the airtightness requirements of the relevant PV standard test. In a humid air environment $(80 \pm 5 \% \mathrm{RH})$, the PCE of packaged PSCs remains unchanged, 
while non-hermetic packaged devices will degrade after about $50 \mathrm{~h}$. It is worth mentioning that all packaged PSCs in this study still maintained stable performance after more than 15 months [104].

\subsection{The Control of Perouskite Crystal Growth}

In 2020, Lv et al. added a series of urea molecules (urea, biurea, or triurea) composed of Lewis base $\left(-\mathrm{NH}_{2}\right)$ and Lewis acid $(-\mathrm{C}=\mathrm{O})$ groups to the perovskite precursor. Urea and biuret are conducive to the growth of large-grain crystals, and there is a correlation between $-\mathrm{C}=\mathrm{O}$ and $-\mathrm{NH}_{2}$ groups and $\mathrm{PbI}_{2}$ and MAI. Triurea molecules are easy to aggregate and adhere to the surface of the perovskite to form a cascade junction, thereby reducing the barrier of electron transfer from the perovskite to the electron transport layer, and can improve the PCE of the device. In addition, depending on the different coordination abilities of the perovskite components, the bound molecules can change the crystallization kinetics. This allows large crystals to grow at low temperatures $\left(60^{\circ} \mathrm{C}\right)$ and associate with counter ions or insufficiently coordinate ions to passivate defects and enhance charge transfer. In order to obtain synergistic benefits from additive engineering, they tried to mix different combinations of additives such as urea/triurea, biuret/triuret, or urea/biuret into the precursor to improve device performance further. It was found that the biuret/triurea mixed additive is most conducive to the growth of large-particle crystals, and the best performance PSCs can be obtained, with a PCE of 21.6\% [105].

In the same year, Huang et al. doped perovskite with diethyl ammonium bromide (DABr) and used in situ dynamic microscopy to study the grain growth mechanism of $\mathrm{DABr}$-doped $\mathrm{MAPbI}_{3}$. The $\mathrm{MAPbI}_{3}$ was doped with different proportions of $\mathrm{DABr}$. The results showed that the addition of $10 \% \mathrm{DABr}$ could obtain a thin film with larger grains (about one $\mu \mathrm{m}$ ) and uniform morphology, which can ensure that the electrode can effectively transport and extract carriers. Moreover, the film has fewer interface traps and can inhibit recombination. This could be due to the alkyl chain of DABr that inhibits the grain growth of $\mathrm{MAPbI}_{3}$ during the spin coating process and induces the crystal grains to merge during the annealing process to obtain micron-sized large grains. It should be concluded that $\mathrm{DABr}$ significantly improves the crystallization of $\mathrm{MAPbI}_{3}$ and reduces the number of defects. The PCE of the obtained PSCs is $19.58 \%$, and the fill factor is $79.81 \%$ [106].

\section{Discussion and Outlook}

With the continuous development of science and technology, humanity's demand for energy is increasing, so the development of sustainable energy is vital. Solar cells can meet this requirement. With the emergence of PSCs, a large number of scientific and technological personnel have devoted themselves to this. Because it has developed rapidly in just ten years, the PCE has increased from $3.8 \%$ to $25.2 \%$. Moreover, it has excellent light absorption performance, a suitable energy band structure, and a bandgap of $1.5 \mathrm{eV}$, which is more ideal than silicon-based solar cells. Therefore, the development prospects of PSCs are undoubted, but there is still a long way to go before its commercialization because the fabrication of large-area and stable PSCs has always been problematic. In particular, as the active area of single solar cell becomes larger, its PCE will become lower. The organic components contained inside are volatile and, therefore, very unstable. However, people continue to explore it, through continuous improvement of precursor engineering and formulation, using more advanced interface engineering to effectively passivate defects, reduce non-radiative recombination, and reduce interface and grain boundary recombination, which have speeded up the preparation of high-quality perovskite films.

Meanwhile, the production and monitor of high-quality perovskite films are inseparable from the advanced characterization techniques, such as SIMS, GIWAXS, and cryoelectron microscope, etc., which help to reveal the in-situ forming film process, crystalline, and their micro-mechanisms for large-area perovskite solar cells. Therefore, the further development of in-situ dynamic characterization techniques and their joint utilization must 
be other focus points in the future. This would significantly promote the production of large area preparation strategies for PSCs, in order to accelerate the commercial process of PSCs. Predictably, we will eventually produce non-lagging, ultra-stable, and high-efficiency PSCs so that it could be commercialized and provide a force for future energy demand.

Author Contributions: T.D., Q.C., L.Y. and M.H.A.: writing original draft. L.Y., Y.D., and Y.Y.: writing-review \& editing. H.L., M.L. and Q.L. are contributing the discussions. All authors have read and agreed to the published version of the manuscript.

Funding: This work is supported by the National Natural Science Foundation of China (Grant nos.U1632121, 11304204), Shanghai Municipal Commission for Science and Technology (No. $20 Z R 146$ 4100), and the Youth Innovation Promotion Association CAS. We thank the Natural Science Foundation of Zhejiang Province (Grant Nos. LQ13A050002, LQ13A040003).

Acknowledgments: We thank the staff from BL01B1, BL11B, BL14B1, BL17B1, BL17U1 and BL19U1 beamlines of Shanghai Synchrotron Radiation Facility for assistance.

Conflicts of Interest: The authors declare that they have no known competing financial interests or personal relationships that could have appeared to influence the work reported in this article.

\section{References}

1. Akihiro, K.; Kenjiro, T.; Yasuo, S.; Miyasaka, T. Organometal halide perovskites as visible-light sensitizers for photovoltaic cells. J. Am. Chem. Soc. 2009, 131, 6050-6051.

2. NREL, Best Research-Cell Efficiencies. Available online: https:/ /www.nrel.gov/pv/cell-efficiency.html (accessed on 30 September 2020).

3. Kim, Y.Y.; Park, E.Y.; Yang, T.Y.; Noh, J.H.; Shin, T.J.; Jeon, N.J.; Seo, J. Fast two-step deposition of Perovskite via mediator extraction treatment for large-area, high-performance perovskite solar cells. J. Mater. Chem. A 2018, 6, 12447-12454. [CrossRef]

4. Giacomo, F.D.; Fledderus, H.; Gorter, H.; Kirchner, G.; De Vries, I.; Dogan, I.; Verhees, W.; Zardetto, V.; Najafi, M.; Zhang, D. Large area $>140 \mathrm{~cm}^{2}$ perovskite solar modules made by sheet to sheet and roll to roll fabrication with $14.5 \%$ efficiency. In Proceedings of the IEEE 7th World Conference on Photovoltaic Energy Conversion (WCPEC), Waikoloa, HI, USA, 10-15 June 2018; pp. 2795-2798. [CrossRef]

5. Jena, A.K.; Kulkarni, A.; Miyasaka, T. Halide Perovskite Photovoltaics: Background, Status, and Future Prospects. Chem. Rev. 2019, 119, 3036-3103. [CrossRef] [PubMed]

6. Boyd, C.C.; Cheacharoen, R.; Leijtens, T. Understanding Degradation Mechanisms and Improving Stability of Perovskite Photovoltaics. Chem. Rev. 2019, 119, 3418-3451. [CrossRef] [PubMed]

7. Kristallogr, Z. Krystallographisch-chemische untersuchungen homologer verbindungen. Chem. Rev. 1884, 8, 246-296.

8. Zhou, Y.; Zhao, Y. Chemical stability and instability of inorganic halide perovskites. Energ. Environ Sci. 2019, 12, 1495-1511. [CrossRef]

9. Chonghea, L.; Xionggang, L.; Weizhong, D. Formability of $\mathrm{ABX}\{\operatorname{sub} 3(\mathrm{X}=\mathrm{F}, \mathrm{Cl}, \mathrm{Br}, \mathrm{I})$ halide perovskites. Acta Crystallogr. 2008, 64, 702-707.

10. Wiley, A.; Dunlap-Shohl, Y. Synthetic Approaches for Halide Perovskite Thin Films. Chem. Rev. 2018, 119, 3193-3295.

11. Travis, W.; Glover, E.N.K.; Bronstein, H. On the application of the tolerance factor to inorganic and hybrid halide perovskites: A revised system. Chem. Sci. 2016, 7, 4548-4556. [CrossRef]

12. Stoumpos, C.C.; Malliakas, C.D.; Kanatzidis, M.G. Semiconducting Tin and Lead Iodide Perovskites with Organic Cations: Phase Transitions, High Mobilities, and Near-Infrared Photoluminescent Properties. Inorg. Chem. 2013, 52, 9019-9038. [CrossRef]

13. Im, J.H.; Lee, C.R.; Lee, J.W. 6.5\% efficient perovskite quantum-dot-sensitized solar cell. Nanoscale 2011, 3, 4088-4093. [CrossRef]

14. Lee, M.M.; Teuscher, J.; Miyasaka, T. Efficient Hybrid Solar Cells Based on Meso-Superstructured Organometal Halide Perovskites. Science 2012, 338, 643-647. [CrossRef] [PubMed]

15. Liu, M.; Johnston, M.B.; Snaith, H.J. Efficient planar heterojunction perovskite solar cells by vapour deposition. Nature 2013, 501, 395-398. [CrossRef] [PubMed]

16. Zhou, H.; Chen, Q.; Li, G. Interface engineering of highly efficient perovskite solar cells. Science 2014, 345, 542-546. [CrossRef]

17. Yang, W.S.; Noh, J.H.; Jeon, N.J. High-performance photovoltaic perovskite layers fabricated through intramolecular exchange. Science 2015, 348, 1234. [CrossRef] [PubMed]

18. Chen, $\mathrm{W}$; $\mathrm{Wu}, \mathrm{Y}$.; Yue, Y. Efficient and stable large-area perovskite solar cells with inorganic charge extraction layers. Science 2015, 350, 944-948. [CrossRef]

19. Wang, Y.; Wu, T.; Barbaud, J. Stabilizing heterostructures of soft perovskite semiconductors. Science 2019, 365, 687-691. [CrossRef]

20. Bi, D.; Yi, C.; Luo, J. Polymer-templated nucleation and crystal growth of perovskite films for solar cells with efficiency greater than $21 \%$. Nat. Energy 2016, 1, 16142. [CrossRef]

21. Yang, W.S.; Park, B.W.; Jung, E.H. Iodide management in formamidinium-lead-halide-based perovskite layers for efficient solar cells. Science 2017, 356, 1376-1379. [CrossRef] 
22. Jeon, N.J.; Na, H.; Jung, E.H.; Yang, T.Y.; Lee, Y.G.; Kim, G.; Shin, H.-W.; Seok, S., II; Lee, J.; Lee, J.; et al. A fluorene-terminated hole-transporting material for highly efficient and stable perovskite solar cells. Nat. Energy 2018, 3, 682-689. [CrossRef]

23. Kim, M.; Kim, G.H.; Lee, T.K. Methylammonium chloride induces intermediate phase stabilization for efficient perovskite solar cells. Joule 2019, 3, 2179-2192. [CrossRef]

24. Tang, S.; Deng, Y.; Zheng, X.; Bai, Y.; Fang, Y.; Dong, Q.; Wei, H.; Huang, J. Composition Engineering in Doctor-Blading of Perovskite Solar Cells. Adv. Energy Mater. 2017, 7, 1700302. [CrossRef]

25. Yang, M.; Li, Z.; Reese, M.O.; Reid, O.G.; Kim, D.H.; Siol, S.; Klein, T.R.; Yan, Y.; Berry, J.J.; van Hest, M.F.A.M.; et al. Perovskite Ink with Wide Processing Window for Scalable Highefficiency Solar Cells. Nat. Energy 2017, 2, 17038. [CrossRef]

26. Kim, J.-E.; Jung, Y.-S.; Heo, Y.-J.; Hwang, K.; Qin, T.; Kim, D.-Y.; Vak, D. Slot Die Coated Planar Perovskite Solar Cells via Blowing and Heating Assisted One Step Deposition. Sol. Energy Mater. Sol. Cells. 2018, 179, 80-86. [CrossRef]

27. Whitaker, J.B.; Kim, D.H.; Larson, B.W.; Zhang, F.; Berry, J.J.; van Hest, M.F.A.M.; Zhu, K. Scalable Slot-die Coating of High Performance Perovskite Solar Cells. Sustain. Energy Fuels 2018, 2, 2442-2449. [CrossRef]

28. Lee, D.; Jung, Y.-S.; Heo, Y.-J.; Lee, S.; Hwang, K.; Jeon, Y.-J.; Kim, J.-E.; Park, J.; Jung, G.Y.; Kim, D.-Y. Slot-Die Coated Perovskite Films Using Mixed Lead Precursors for Highly Reproducible and Large-Area Solar Cells. ACS Appl. Mater. Interfaces 2018, 10, 16133-16139. [CrossRef]

29. Mathies, F.; Eggers, H.; Richards, B.S.; Hernandez-Sosa, G.; Lemmer, U.; Paetzold, U.W. Inkjet-Printed Triple Cation Perovskite Solar Cells. ACS Appl. Energy Mater. 2018, 1, 1834-1839. [CrossRef]

30. Mathies, F.; Abzieher, T.; Hochstuhl, A.; Glaser, K.; Colsmann, A.; Paetzold, U.W.; Hernandez-Sosa, G.; Lemmer, U.; Quintilla, A. Multipass Inkjet Printed Planar Methylammonium Lead Iodide Perovskite Solar Cells. J. Mater. Chem. A 2016, 4, 19207-19213. [CrossRef]

31. Li, S.G.; Jiang, K.J.; Su, M.J.; Cui, X.P.; Huang, J.H.; Zhang, Q.Q.; Zhou, X.Q.; Yang, L.M.; Song, Y.-L. Inkjet Printing of CH3NH3PbI3 on a Mesoscopic TiO2 Film for Highly Efficient Perovskite Solar Cells. J. Mater. Chem. A 2015, 3, 9092-9097. [CrossRef]

32. Cao, K.; Zuo, Z.; Cui, J.; Shen, Y.; Moehl, T.; Zakeeruddin, S.M.; Gratzel, M.; Wang, M. Efficient Screen Printed Perovskite Solar Cells Based on Mesoscopic TiO2/Al2O3/NiO/carbon Architecture. Nano Energy 2015, 17, 171-179. [CrossRef]

33. Priyadarshi, A.; Bashir, A.; Gunawan, J.T.; Haur, L.J.; Bruno, A.; Akhter, Z.; Mathews, N.; Mhaisalkar, S.G. Simplified Architecture of a Fully Printable Perovskite Solar Cell Using a Thick Zirconia Layer. Energy Technol. 2017, 5, 1866-1872. [CrossRef]

34. Mohamad, D.K.; Griffin, J.; Bracher, C.; Barrows, A.T.; Lidzey, D.G. Spray-Cast Multilayer Organometal Perovskite Solar Cells Fabricated in Air. Adv. Energy Mater. 2016, 6, 1600994. [CrossRef]

35. Lan, D.H.; Hong, S.H.; Chou, L.H.; Wang, X.F.; Liu, C.L. High Throughput Two-step Ultrasonic Spray Deposited $\mathrm{CH}_{3} \mathrm{NH}_{3} \mathrm{PbI}_{3}$ Thin Film Layer for Solar Cell Application. J. Power Sources 2018, 390, 270-277. [CrossRef]

36. Ono, L.K.; Leyden, M.R.; Wang, S.; Qi, Y. Organometal Halide Perovskite Thin Films and Solar Cells by Vapor Deposition. J. Mater. Chem. A 2016, 4, 6693-6713. [CrossRef]

37. Leyden, M.R.; Jiang, Y.; Qi, Y. Chemical Vapor Deposition Grown Formamidinium Perovskite Solar Modules with High Steady State Power and Thermal Stability. J. Mater. Chem. A 2016, 4, 13125-13132. [CrossRef]

38. Chen, H.; Wei, Z.; Zheng, X.; Yang, S. A Scalable Electrodeposition Route to the Low-cost, Versatile and Controllable Fabrication of Perovskite Solar Cells. Nano Energy 2015, 15, 216-226. [CrossRef]

39. Charles, U.A.; Ibrahim, M.A.; Teridi, M.A.M. Electrodeposition of Organic-inorganic Tri-halide Perovskites Solar Cell. J. Power Sources 2018, 378, 717-731. [CrossRef]

40. Fei, C.; Li, B.; Zhang, R. Highly Efficient and Stable Perovskite Solar Cells Based on Monolithically $\mathrm{Grained}_{\mathrm{CH}} \mathrm{NH}_{3} \mathrm{PbI}_{3} \mathrm{Film}_{\text {. }}$ Adv. Energy Mater. 2016, 7, 1602017. [CrossRef]

41. Wu, Y.Z.; Xie, F.X.; Chen, H. Thermally Stable MAPbI3 Perovskite Solar Cells with Efficiency of $19.19 \%$ and Area over $1 \mathrm{~cm}^{2}$ achieved by Additive Engineering. Adv. Mater. 2017, 29, 1701073. [CrossRef] [PubMed]

42. Watthage, S.C.; Song, Z.; Shrestha, N. Enhanced Grain Size, Photoluminescence, and Photoconversion Efficiency with Cadmium Addition during the Two-Step Growth of CH3NH3PbI3. ACS Appl. Mater. Interfaces 2016, 9, 2334-2341. [CrossRef]

43. Wang, J.T.W.; Wang, Z.P.; Pathak, S.; Zhang, W. Efficient perovskite solar cells by metal ion doping. Energy Environ Sci. 2016, 9 , 2892-2901. [CrossRef]

44. Ke, W.; Xiao, C.; Wang, C. Employing Lead Thiocyanate Additive to Reduce the Hysteresis and Boost the Fill Factor of Planar Perovskite Solar Cells. Adv Mater. 2016, 28, 5214. [CrossRef]

45. Chiang, C.H.; Wu, C.G. Bulk heterojunction perovskite-PCBM solar cells with high fill factor. Nat. Photon. 2016, 10, 196. [CrossRef]

46. Li, X.; Bi, D.; Yi, C. A vacuum flash-assisted solution process for high-efficiency large-area perovskite solar cells. Science 2016, 353, 58-62. [CrossRef]

47. Mei, A.; Li, X.; Liu, L.; Ku, Z.; Liu, T.; Rong, Y.; Xu, M.; Hu, M.; Chen, J.; Yang, Y.; et al. A hole-conductor-free, fully printable mesoscopic perovskite solar cell with high stability. Science 2014, 345, 295-298. [CrossRef]

48. Yang, S.; Dai, J.; Yu, Z. H Tailoring Passivation Molecular Structues for Extremely Small Open-Circuit Voltage Loss in Perovskite Solar Cells. J. Am. Chem. Soc. 2019, 141, 5781-5787. [CrossRef]

49. Cao, Y.; Wang, N.N.; Tian, H. Perovskite light-emitting diodes based on spontaneously formed submicrometre-scale structures. Nature 2018, 562, 249-253. [CrossRef] 
50. Lee, J.W.; Kim, H.S.; Park, N.G. Lewis Acid-Base Adduct Approach for High Efficiency Perovskite Solar Cells. Acc. Chem. Res. 2016, 49, 311-319. [CrossRef] [PubMed]

51. Hu, J.; Wang, C.; Qiu, S. Spontaneously Self ssembly of a 2D/3D Heterostructure Enhances the Efficiency and Stability in Printed Perovskite Solar Cells. Adv. Energy Mater. 2020, 10, 2000173. [CrossRef]

52. Liao, H.; Guo, P.; Hsu, C.P. Enhanced Efficiency of Hot-Cast Large-Area Planar Perovskite Solar Cells/Modules Having Controlled Chloride Incorporation. Adv. Energy Mater. 2017, 7, 1601660. [CrossRef]

53. Bu, T.; Liu, X.; Zhou, Y. A novel quadruple-cation absorber for universal hysteresis elimination for high efficiency and stable perovskite solar cells. Energy Environ. Sci. 2017, 10, 2509-2515. [CrossRef]

54. Agresti, A.; Pescetelli, S.; Palma, A.L. Two-Dimensional Material Interface Engineering for Efficient Perovskite Large-Area Modules. ACS Energy Lett. 2019, 4, 1862-1871. [CrossRef]

55. Bella, F.; Renzi, P.; Cavallo, C. Caesium for Perovskite Solar Cells: An Overview. Chem. A Eur. J. 2018, 24, 12183-12205. [CrossRef]

56. Saliba, M.; Matsui, T.; Seo, J.Y.; Domanski, K. Cesium-containing triple cation perovskite solar cells: Improved stability, reproducibility and high efficiency. Energy Environ. Sci. 2016, 9, 1989-1997. [CrossRef] [PubMed]

57. Chen, H.; Yang, S. Methods and strategies for achieving high-performance carbon-based perovskite solar cells without hole transport materials. J. Mater. Chem. A 2019, 7, 15476-15490. [CrossRef]

58. Fagiolari, L.; Bella, F. Carbon-based materials for stable, cheaper and large-scale processable perovskite solar cells. Energ. Environ. Sci. 2019, 12, 3437-3472. [CrossRef]

59. Wu, M.; Sun, M.; Zhou, H.; Ma, J.-Y.; Ma, T. Carbon Counter Electrodesin Dye-Sensitized and Perovskite Solar Cells. Adv. Funct. Mater. 2020, 30, 1906451. [CrossRef]

60. Hou, Y.; Du, X.; Scheiner, S. A generic interface to reduce the efficiency-stability-cost gap of perovskite solar cells. Science 2017, 358, 1192-1197. [CrossRef]

61. Yang, Y.; Yang, L.; Feng, S. Interfacial engineering and film-forming mechanism of perovskite films revealed by synchrotron-based GIXRD at SSRF for highperformance solar cells. Mater. Today Adv. 2020, 6, 100068. [CrossRef]

62. Jeong, M.; Choi, I.W.; Go, E.M. Stable perovskite solar cells with efficiency exceeding $24.8 \%$ and $0.3-\mathrm{V}$ voltage loss. Science 2020, 369, 1615-1620. [PubMed]

63. Hendriks, K.H.; van Franeker, J.J.; Bruijnaers, B.J. 2-Methoxyethanol as a new solvent for processing methylammonium lead halide perovskite solar cells. J. Mater. Chem. A 2017, 5, 2346-2354. [CrossRef]

64. Noel, N.K.; Habisreutinger, S.N.; Wenger, B. A low viscosity, low boiling point, clean solvent system for the rapid crystallisation of highly specular perovskite films. Energy Environ. Sci. 2016, 10, 145-152. [CrossRef]

65. Deng, Y.; Van Brackle, C.H.; Dai, X. Tailoring solvent coordination for high-speed, room-temperature blading of Perovskite photovoltaic films. Sci. Adv. 2019, 5, 7537. [CrossRef] [PubMed]

66. Deng, Y.; Zheng, X.; Bai, Y. Surfactant-controlled ink drying enables high-speed deposition of perovskite films for efficient photovoltaic modules. Nat. Energy 2018, 3, 560-566. [CrossRef]

67. Huang, S.H.; Guan, C.K.; Lee, P.H.; Huang, H.C.; Li, C.F.; Huang, Y.C.; Su, W.F. Toward All Slot-Die Fabricated High Efficiency Large Area Perovskite Solar Cell Using Rapid Near Infrared Heating in Ambient Air. Adv. Energy Mater. 2020, 10, 2001567. [CrossRef]

68. Ye, T.; Han, G.; Surendran, A. Large area, high efficiency and stable Perovskite solar cells enabled by fine control of intermediate phase. Sol. Energy Mater. Sol. Cells 2019, 201, 110113. [CrossRef]

69. Jung, E.H.; Jeon, N.J.; Park, E.Y. Efficient, stable and scalable perovskite solar cells using poly(3-hexylthiophene). Nature 2019, 567, 511. [CrossRef]

70. Bi, E.; Tang, W.; Chen, H. Efficient perovskite solar cell modules with high stability enabled by iodide diffusion barriers. Joule 2019, 3, 2748-2760. [CrossRef]

71. Lou, L.; Liu, T.; Xiao, J. Controlling Apparent Coordinated Solvent Number in the Perovskite Intermediate Phase Film for Developing Large-Area Perovskite Solar Modules. Energy Technol. 2019, 8, 1900972. [CrossRef]

72. Luo, L.; Zhang, Y.; Chai, N. Large-area perovskite solar cells with $\mathrm{Cs}_{\mathrm{x}} \mathrm{FA}_{1-\mathrm{x}} \mathrm{PbI}_{3-\mathrm{y}} \mathrm{Br}_{\mathrm{y}}$ thin films deposited by a vapor-solid reaction method. J. Mater. Chem. A 2018, 6, 21143-21148. [CrossRef]

73. Jang, G.; Kwon, H.C.; Ma, S. Cold Antisolvent Bathing Derived Highly Efficient Large-Area Perovskite Solar Cells. Adv. Energ. Mater. 2019, 9, 1901719. [CrossRef]

74. Qiu, L.; He, S.; Jiang, Y. Hybrid chemical vapor deposition enables scalable and stable Cs-FA mixed cation perovskite solar modules with a designated area of $91.8 \mathrm{~cm}^{2}$ approaching 10\% efficiency. J. Mater. Chem. 2019, 7, 6920-6929. [CrossRef]

75. Giacomo, F.D.; Shanmugam, S.; Fledderus, H. Up-scalable sheet-to-sheet production of high efficiency perovskite module and solar cells on 6-in. substrate using slot die coating. Sol. Energy Mater Sol. Cells 2017, 181, 53-59. [CrossRef]

76. Wang, Z.K.; Gong, X.; Li, M. Induced Crystallization of Perovskites by a Perylene Underlayer for High-Performance Solar Cells Acs Nano. 2016, 10, 5479-5489. [CrossRef]

77. Park, N.G.; Grätzel, M.; Miyasaka, T.; Zhu, K.; Emery, K. Towards stable and commercially available perovskite solar cells. Nat. Energy 2016, 1, 16152. [CrossRef]

78. Singh, T.; Singh, J.; Miyasaka, T. Role of Metal Oxide Electron-Transport Layer Modification on the Stability of High Performing Perovskite Solar Cells. ChemSusChem 2016, 9, 2559-2566. [CrossRef] [PubMed] 
79. Ahn, N.; Kwak, K.; Jang, M.S. Trapped charge-driven degradation of perovskite solar cells. Nat. Commun. 2016, 7, 13422. [CrossRef]

80. Saliba, M.; Matsui, T.; Domanski, K. Incorporation of rubidium cations into perovskite solar cells improves photovoltaic performance. Science 2016, 354, 206-209. [CrossRef] [PubMed]

81. Tsai, H. High-efficiency two-dimensional Ruddlesden-Popper perovskite solar cells. Nature 2016, 536, 312-316. [CrossRef]

82. Shao, Y.C.; Yuan, Y.B.; Huang, J.S. Correlation of energy disorder and open-circuit voltage in hybrid perovskite solar cells. Nat. Energy 2015, 1, 15001. [CrossRef]

83. Wang, Q.; Dong, Q.F.; Li, T. Thin Insulating Tunneling Contacts for Efficient and Water-Resistant Perovskite Solar Cells. Adv. Mater. 2016, 28, 6734. [CrossRef] [PubMed]

84. Li, Y.; Zhao, Y.; Chen, Q. A Multifunctional Fullerene Derivative for Interface Engineering in Perovskite Solar Cells. J. Am. Chem. Soc. 2015, 137, 15540-15547. [CrossRef] [PubMed]

85. Giordano, F.; Abate, A.; Baena, J.P.C. Enhanced electronic properties in mesoporous $\mathrm{TiO}_{2}$ via lithium doping for high-efficiency perovskite solar cells. Nat. Commun. 2016, 7, 10379. [CrossRef]

86. Tan, H.; Jain, A.; Voznyy, O. Efficient and stable solution-processed planar perovskite solar cells via contact passivation. Science 2017, 355, 722-726. [CrossRef]

87. Liu, D.; Kelly, T.L. Perovskite Solar Cells with a Planar Heterojunction Structure Prepared Using Room- Temperature Solution Processing Techniques. Nat. Photonics 2014, 8, 133. [CrossRef]

88. Jiang, Q.; Zhang, L.; Wang, H.; Yang, X.; Meng, J.; Liu, H.; Yin, Z.; Wu, J.; Zhang, X. Enhanced Electron Extraction Using SnO2 for High-Efficiency Planar-Structure HC(NH2)2PbI3-Based Perovskite Solar Cells. Nat. Energy 2016, 2, 1667. [CrossRef]

89. Xiong, L.; Guo, Y.; Wen, J.; Liu, H.; Yang, G.; Fang, G. Review on the Application of $\mathrm{SnO}_{2}$ in Perovskite Solar Cells. Adv. Funct. Mater. 2018, 28, 1802757. [CrossRef]

90. Mali, S.S.; Patil, J.V.; Kim, H.; Hong, C.K. Synthesis of $\mathrm{SnO}_{2}$ nanofibers and nanobelts electron transporting layer for efficient perovskite solar cells. Nanoscale 2018, 10, 8275. [CrossRef]

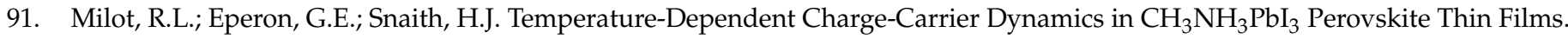
Adv. Funct. Mater. 2015, 25, 6218. [CrossRef]

92. Zhen, J.; Zhou, W.; Chen, M.; Yang, S. Pyridine-functionalized fullerene additive enabling coordination interactions with $\mathrm{CH} 3 \mathrm{NH} 3 \mathrm{PbI} 3$ perovskite towards highly efficient bulk heterojunction solar cells. J. Mater. Chem. A 2019, 7, 2754. [CrossRef]

93. $\mathrm{Hu}, \mathrm{W} . ;$ Yang, Y.; Xu, Q. Red-Carbon-Quantum-Dot-Doped $\mathrm{SnO}_{2}$ Composite with Enhanced Electron Mobility for Efficient and Stable Perovskite Solar Cells. Adv. Mater. 2020, 32, 1906374. [CrossRef] [PubMed]

94. Weerasinghe, H.C.; Dkhissi, Y.; Scully, A.D.; Caruso, R.A.; Cheng, Y.B. Encapsulation for improving the lifetime of flexible perovskite solar cells. Nano Energy 2015, 18, 118-125. [CrossRef]

95. Hwang, I.; Jeong, I.; Lee, J.; Ko, M.J.; Yong, K. Enhancing stability of perovskite solar cells to moisture by the facile hydrophobic passivation. ACS Appl. Mater. Interfaces 2015, 7, 17330-17336. [CrossRef] [PubMed]

96. Kaltenbrunner, M.; Adam, G.; Głowacki, E.D.; Drack, M. Flexible high power-per-weight perovskite solar cells with chromium oxide-metal contacts for improved stability in air. Nat. Mater. 2015, 14, 1032-1039. [CrossRef]

97. You, J.; Meng, L.; Song, T.-B.; Guo, T.-F. Improved air stability of Perovskite solar cells via solution-processed metal oxide transport layers. Nat. Nanotechnol. 2016, 11, 75-81. [CrossRef] [PubMed]

98. Domanski, K.; Correa-Baena, J.P.; Grätzel, M. Not all that glitters is gold: Metal-migrationinduced degradation in Perovskite solar cells. ACS Nano 2016, 10, 6306-6314. [CrossRef]

99. Bella, F.; Griffini, G.; Correa-Baena, J.P. Improving efficiency and stability of perovskite solar cells with photocurable fluoropolymers. Science 2016, 354, 203-206. [CrossRef]

100. Kim, B.J.; Kim, D.H.; Kang, S.Y.; Ahn, S.D. A thin film encapsulation layer fabricated via initiated chemical vapor deposition and atomic layer deposition. J. Appl. Polym. Sci. 2014, 131, 40974. [CrossRef]

101. Kim, B.J.; Park, H.; Seong, H.; Lee, M.S.; Kwon, B.-H.; Kim, D.H.; Lee, Y.I.; Lee, H.; Lee, J.-I.; Im, S.G. A Single-Chamber System of Initiated Chemical Vapor Deposition and Atomic Layer Deposition for Fabrication of Organic/Inorganic Multilayer Films. Adv. Eng. Mater. 2017, 19, 1600819. [CrossRef]

102. Kim, B.J.; Han, D.; Yoo, S.; Im, S.G. Upgrading of pyrolysis bio-oil using $\mathrm{WO}_{3} / \mathrm{ZrO}_{2}$ and Amberlyst catalysts: Evaluation of acid number and viscosity. Korean J. Chem. Eng. 2017, 34, 892.

103. Lee, Y., II; Jeon, N.J.; Kim, B.J.; Shim, H.; Yang, T.-Y.; Seok, S., II; Seo, J.; Im, S.G. A Low-Temperature Thin-Film Encapsulation for Enhanced Stability of a Highly Efficient Perovskite Solar Cell. Adv. Energy Mater. 2018, 8, 1701928. [CrossRef]

104. Emami, S.; Martins, J.; Ivanou, D. Advanced hermetic encapsulation of perovskite solar cells: The route to commercialization. J. Mater. Chem. 2020, 8, 2654-2662. [CrossRef]

105. Lv, Y.; Zhang, H.; Wang, J. All-in-One Deposition to Synergistically Manipulate Perovskite Growth for High-Performance Solar Cell. Research 2020, 2020, 2763409. [CrossRef] [PubMed]

106. Huang, X.; Bi, W.; Jia, P.; Cui, Q.; Hu, Y.; Lou, Z.; Hou, Y.; Teng, F. Grain Growth of MAPbI3 via Diethylammonium Bromide Induced Grain Mergence. ACS Appl. Mater. Interfaces 2020, 12, 16707-16714. [CrossRef] 